\title{
Pneumococcal pneumonia and invasive pneumococcal disease: immunopathogenesis and diagnosis
}

\author{
Gina Amanda ${ }^{1, \dagger}$, Dianiati Kusumo Sutoyo ${ }^{1}$, Erlina Burhan ${ }^{1}$
}

Abstract

${ }^{1}$ Department of Pulmonology and Respiratory Medicine, Faculty of Medicine Universitas Indonesia, Persahabatan Hospital, Jakarta, Indonesia

English:

Streptococcus pneumoniae is the most common aetiology of community-acquired pneumonia (CAP). It has many virulence factors, the most important being a polysaccharide capsule (Cps). There are 97 different serotypes of pneumococcal based on Cps which include both colonization and invasive serotypes. Pneumococcal pneumonia may exist as a result of either aspiration of bacteria in the nasopharynx or inhalation of droplet nuclei which contains bacteria until they reach the lower respiratory tract. This condition will activate both innate and adaptive immune system. The diagnosis of pneumococcal pneumonia is established in a patient who has the signs and symptoms of pneumonia, accompanied by the detection of S. pneumoniae in microbiology examination. Pneumococcus may also penetrate into a normally sterile site such as bloodstream, meninges, and pleural cavity, and infection of pneumococcus in those sites are defined as an invasive pneumococcal disease (IPD). High bacterial load, dysfunction of the immune system, and co-colonization of another microorganism may also lead to IPD.

Keywords

Streptococcus pneumoniae $\cdot$ polysaccharide capsule $\bullet$ serotype $\bullet$ pneumococcal pneumonia $\bullet$ invasive pneumococcal disease

\section{Pneumonia pneumococică și boala pneumococică invazivă: imunopatogeneză și diagnostic}

Rezumat

Romanian:

Streptococcus pneumoniae este cel mai frecvent agent etiologic al pneumoniei comunitare dobândite. Are foarte mulți factori virulenți, cel mai important fiind capsula polizaharidică. Există 97 de serotipuri diferite de capsule polizaharidice pneumococice care includ ambele forme, de colonizare și de invazivitate. Pneumonia pneumococică poate fi rezultatul fie al aspirației bacteriei din nazofaringe, fie al inhalării de picături care conțin bacteria și care ajung în tractul respirator inferior. În acest mod sunt activate ambele sisteme imunitare, înnăscut și dobândit. D̉iagnosticul pneumoniei penumococice se stabilește la un pacient cu semne și simptome de pneumonie, asociate cu identificarea S. pneumoniae la examenul microbiologic. Pneumococul poate pătrunde și în locurile în mod normal sterile ale organismului ca sângele, meningele, cavitatea pleurală, determinând pneumonia penumococică invazivă. Încărcătura bacteriană ridicată, disfuncția sistemului imunitar și colonizarea cu un alt microorganism pot duce de asemenea la o boală pneumococică invazivă.

Cuvinte-cheie

Streptococcus pneumoniae • capsulă polizaharidică • serotip • pneumonie pneumococică • boală pneumococică invazivă

${ }^{+}$Corresponding author: Gina Amanda

E-mail: gina_amanda@ymail.com

כ Open Access. @ 2019 Amanda et al., published by Sciendo

(@) Br.Nc-ND This work is licensed under the Creative Commons Attribution-NonCommercial-NoDerivs 4.0 License. 


\section{Introduction}

Streptococcus pneumoniae is the most common aetiology of community-acquired pneumonia (CAP) worldwide. There are $36 \%$ of cases of pneumococcal pneumonia in the United States (1). Data from Asia revealed that the incidences of pneumococcal pneumonia are 9.1-65\% in Japan, 13.5-60.8\% in South Korea, 3.4-35.8\% in India, and 5.8\% in Thailand $(2-5)$. S. pneumoniae is a major human pathogen that frequently colonizes in the nasopharynx, and it will be the source of disease transmission. In a healthy individual, colonies only cause asymptomatic carrier whereas, in a susceptible individual, colonies may invade to other body parts and lead to pneumococcal disease. This nasopharyngeal (NP) colonization can be aspirated or inhaled into the lower airway and can induce pneumonia. They can also penetrate into a sterile body fluid such as pleural fluid, blood, or cerebrospinal fluid (CSF), and these conditions are defined as an invasive pneumococcal disease (IPD) (6).

\section{S. pneumoniae}

S. pneumoniae is a Gram-positive, lancet-shaped bacterium, usually seen as diplococci, but may be found as a short chain
(7-9). Pneumococci are 0.5-1.25 mm in diameter, non-motile, and do not form spores. Their best growth requires $5 \%$ of carbon dioxide and needs catalase to neutralize a large number of hydrogen peroxides which are produced by bacteria. On blood agar, pneumococci are shown as glisten colonies and form a zone of alpha-haemolysis that has a greenish colour. This zone differentiates pneumococci with beta-haemolytic bacteria, but it is also found in commensal streptococci such as Streptococcus viridans. Optochin and bile solubility test may be performed to distinguish S. pneumoniae and $S$. viridans. In the optochin test, $S$. pneumoniae may result in inhibition zone about $\geq 16 \mathrm{~mm}$. In the bile solubility test, sodium deoxycholate will lyse the pneumococcal cell wall, so it is demonstrated that $S$. pneumoniae is bile soluble whereas other alpha-haemolytic bacteria are bile resistant (9).

Pneumococcus has several virulence factors including polysaccharide capsule (Cps), which is the main component, pneumolysin toxin, surface protein, and enzymes (Figure 1) (7). Recently, there are 97 serotypes of pneumococcus which are identified based on the antigenic and biochemical characteristics of Cps. Several methods, i.e. Quellung test, latex agglutination test, and nucleotide sequencing test, are used to detect the serotype of pneumococcus. When serotypes are identifiable, they are known as a typable capsule. On the contrary, the non-typable capsule

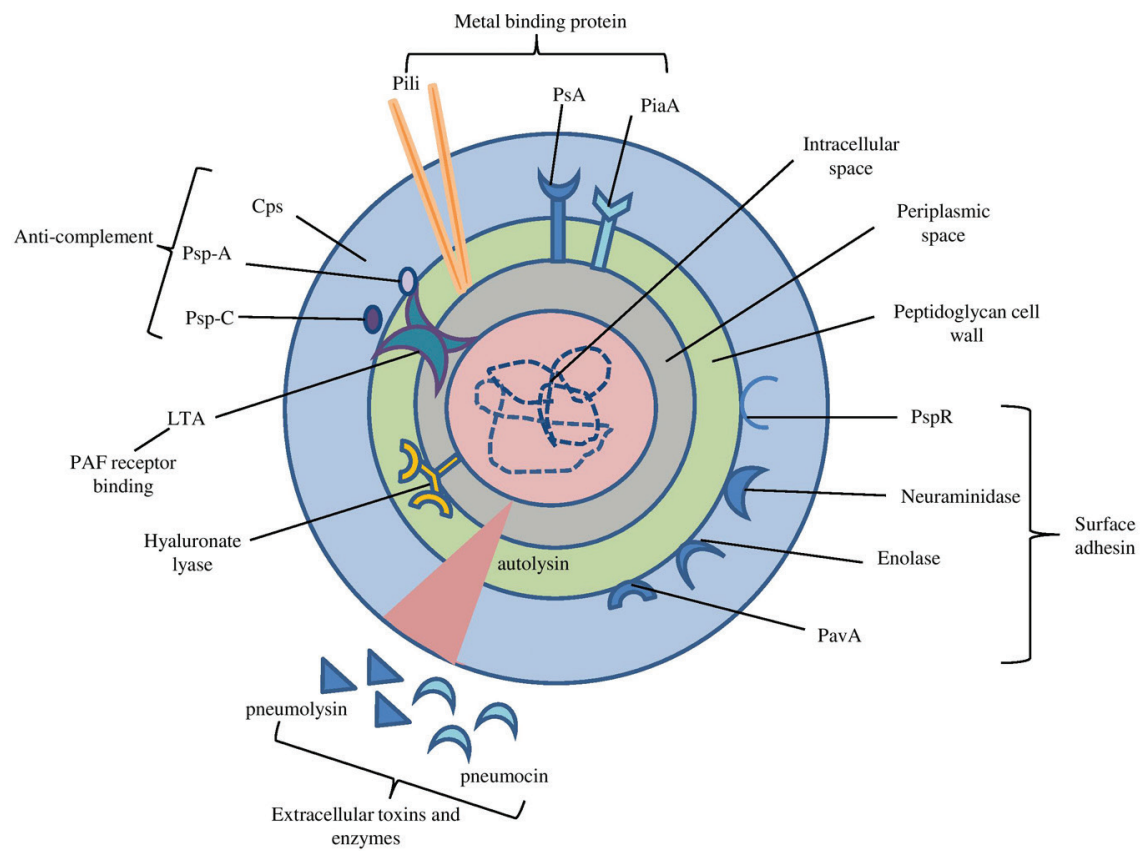

Figure 1. Virulence factors of $S$. pneumoniae. The figure is adapted with modification from Van der Poll T, Opal SM. Pathogenesis, treatment, and prevention of pneumococcal pneumonia. Lancet 2009;374(9700):1543-56.

S. pneumoniae, Streptococcus pneumoniae.

$\mathrm{PsA}=$ pneumococcal surface antigen $\mathrm{A}$. PiaA/PiuA = pneumococcal iron acquisition and uptake. PspR = pneumococcal serine-rich repeat protein. PavA = pneumococcal adhesion and virulence. LTA = lipoteichoic acid. 
is defined as pneumococci in which the serotype is undetected and usually discovered in non-encapsulated pneumococci (10).

Pneumococcal serotypes are also divided into two groups based on their ability to overcome the immune response: colonization and invasive serotypes (11). Colonization serotypes are resistant to non-opsonic neutrophils and cause NP carriage, but if they enter the lower airway, they will be destroyed by alveolar macrophage (AM) and complement system easily. Invasive serotypes can be cleaned by neutrophils in the upper airway, but they are resistant to AM and complement system when they spread to the lower airway (6).

Phase variation is one of the pneumococci capabilities to change its phenotype between transparent and opaque by increasing the encapsulation $(11,12)$. Transparent phenotype that plays a role in colonization has a thin cell wall, low expression of the pneumococcal surface protein (Psp)-A, high expression of adhesin, choline-binding protein (Cbp)-A, and autolysin. Conversely, opaque phenotype has a thick cell wall, high expression of Psp-A, low expression of Cbp-A, and resistance to opsonophagocytosis and is often found in circulation $(13,14)$.

\section{Pneumococcal pneumonia}

Pneumococcal pneumonia is defined as pneumonia caused by $S$. pneumoniae (15). The incidences and serotype distributions vary through time and regions. Some factors may contribute to this condition such as vaccination programme, antibiotic use, socio-economic status, and the age of the population (16).

\section{Pathogenesis}

NP colonization is an essential step towards pneumococcal disease including pneumococcal pneumonia. The link between pneumococcal carriage and disease is usually found in children. A study by Greenberg et al. revealed that children with pneumonia were carriage of $S$. pneumoniae and the serotypes in NP isolates were concordant with serotypes causing pneumonia (14). The rate of NP carriage in adults is lower than that in children (17). However, contact with children may enhance adult carriage (18).

Mechanism of NP colonization of pneumococcus involves adherence of bacteria to epithelial cell via its receptors and activation of the host immune system. In normal mucosa, the bacterial attachment is inhibited by local innate immunity such as saliva, cough reflex, and mucus layer. Then, the cilia movement will transfer bacteria out of the respiratory tract. The mucosa releases lysozyme, lactoferrin, and surfactant to limit bacterial growth $(19,20)$. To survive from the mucosa barrier, pneumococci also produce several enzymes. They are neuraminidase, $\beta$-galactosidase, and $\beta-\mathrm{N}$-acetylglucosaminidase that degrade mucus and inhibit mucociliary clearance. Autolysin facilitates pneumolysin release to destroy the epithelial cells and reduce cilia movement. Cps and other pneumococcal proteins including Psp-A, Cbp-A, and enolase prevent complement deposition. Cbp-E inhibits neutrophil recruitment by degrading plateletactivating factor (PAF). Furthermore, phosphorylcholine (ChoP), a component of teichoic acid in the bacterial cell wall, binds to PAF receptors, whereas Cbp-A binds to polymeric immunoglobulin receptor (plgR), which is the secretory component of epithelial cells (Figure 2) (19).

In addition to mucosa that acts as the physical barrier of innate immunity, several cytokines and inflammatory mediators are released after pneumococci were recognized by antigen-presenting cells (APCs). They play a role in the recruitment of leukocytes from the blood vessel into the mucosa of the respiratory tract. Mechanism of systemic innate immunity involves either the production of C-reactive protein or the activation of the complement system which stimulates polymorphonuclear (PMN) cells and macrophages in the opsonization of bacteria. Activation of the adaptive immune system consists of a local and systemic response. Pneumococci initiate mucosaassociated lymphoid tissue to produce immunoglobulin (Ig)-A which prevents bacteria invasion to mucosa membranes. Then, both B cell and T cell are activated as part of the systemic adaptive immune response. Systemic antibodies such as anti-capsular polysaccharide and anti-protein pneumococcal antibody will be produced as the response to pneumococcal colonization. Most of the carriage is asymptomatic until pneumococcal clearance is completed $(20,21)$.

Pneumococcal pneumonia occurs after either bacterial aspiration or inhalation of droplet nuclei is presented (20). Bacterial load, synergism effect between viral and pneumococcal infection, the morphology of Cps, and host immune defence influence the onset of disease (10). S. pneumoniae will be recognized by $\mathrm{AM}$ via its receptors including class A scavenger receptor; macrophage receptor with collagenous structure (MARCO) that binds to internal site of pneumococcus, toll-like receptor (TLR)-2 that binds to bacterial cell wall, TLR-4 as the receptor of pneumolysin, and TLR-9 for deoxyribonucleic acid (DNA) of bacterial detection. The AM only has the ability to phagocyte a small number of pneumococci. Furthermore, AM and epithelial cells release cytokines such as tumour necrosis factor (TNF)- $\alpha$, interleukin (IL)-8, and chemokine CXC which activate neutrophil response, so they will migrate from the bloodstream to alveoli. After the process of phagocytosis, neutrophils become apoptosis. They will be followed by macrophage apoptosis that declines TNF- $\alpha$ expression; 
thus, it reduces neutrophil migration. These dead cells are removed by macrophages efferocytosis, and the resolution phase is begun $(6,15,21)$.

Adaptive immunity is also critical to the host response to pneumococci. B cells produce Ig that is required for opsonophagocytosis process. T-CD4 ${ }^{+}$cells may contribute to the optimal response against pneumococci such as improving bacterial clearance by $\mathrm{T}$ helper (Th)-17. T-CD8 ${ }^{+}$cells will regulate Th-17 cell number, produce chemokine $\mathrm{CXC}$, and recruit neutrophils. Following the resolution phase, memory $T$ cells still persist in alveoli $(6,15,21)$.

\section{Diagnosis}

The clinical features of pneumococcal pneumonia are similar to other forms of typical pneumonia. The symptoms are fever, malaise, productive cough, shortness of breath, and pleuritic pain. The sputum may be seen as rusty red colour or contains streaks of blood (15). Gastrointestinal symptoms including nausea, vomiting, and diarrhoea may be found in 15-20\% cases of pneumococcal pneumonia. In geriatric patients, pneumococcal pneumonia symptoms are unspecified (22). Sometimes, extrapulmonary signs such as meningitis, sepsis, peritonitis, and mastoiditis emerge earlier than pneumonia signs (15). Radiological findings in pneumococcal pneumonia include infiltrating in one or several segments of a lobe, lobar consolidation, air bronchogram, and pleural effusion $(22,23)$.
Etiological diagnosis of pneumococcal pneumonia may be established through either conventional or molecular methods. Conventional methods include Gram staining, sputum, and blood or pleural fluid culture. Gram stain of sputum could be strongly suggestive of pneumococcal pneumonia if it shows the presence of Gram-positive diplococci and fulfils Bartlett criteria, i.e. $<10$ epithelial cells and $>25$ PMN cells. The limitations of Gram staining are inadequate sputum collection, antibiotic administration before specimen collection, and availability of skilled analyst. A sputum culture is a further step for the identification of pneumococcal pneumonia, but the diagnostic sensitivity varies, ranging between $29 \%$ and $94 \%$. A false negative result is related to inadequate sampling, delayed processing of specimen, and antibiotic therapy before obtaining the specimen. A false positive result is often found in NP carriage, mainly among children; therefore, the result of sputum culture should be interpreted with Gram staining (24). A definite diagnosis of pneumococcal pneumonia is determined if $S$. pneumoniae could be isolated from sterile body sites such as blood or pleural fluid. The rate of a positive result in blood or pleural fluid culture is low. Bacteraemia is only found $<10 \%$ among pneumococcal pneumonia patients. Pneumonia without bacteraemia, autolysis in the stationary phase, prior to an antibiotic, the inadequate sample volume are factors that influence the result of blood and pleural fluid culture. The limitation of a conventional method to detect pneumococcus is a false negative result and it

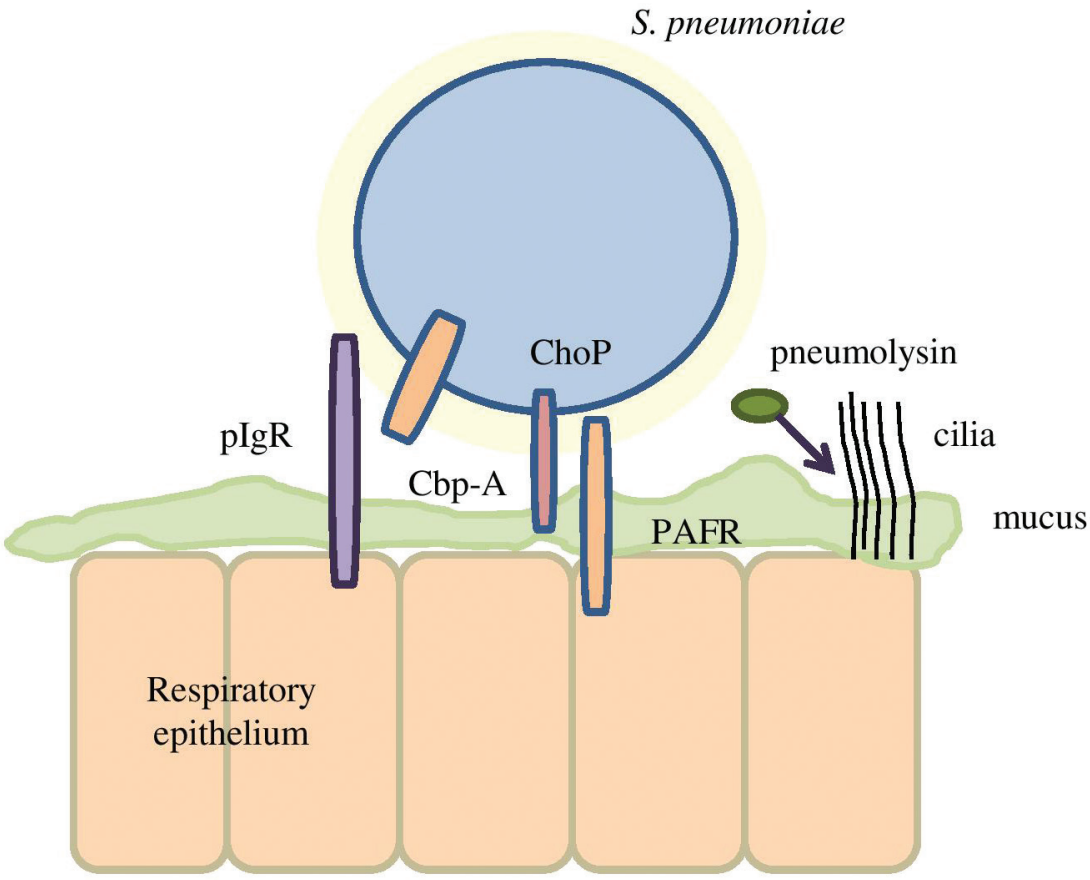

Figure 2. Mechanism of pneumococcal colonization in the respiratory tract. The figure is adapted with modification from Wyllie $A L$, Rümke LW, Arp K, Bosch AA, Bruin JP, Rots NY, et al. Molecular surveillance on Streptococcus pneumoniae carriage in non-elderly adults; little evidence for pneumococcal circulation independent from the reservoir in children. Sci Rep 2016;6:34888. 
needs several days for culture procedures. The molecular method is developed to discover pneumococci quickly, and by using this method the administration of antibiotic does not impact the result. These tests include teichoic acid (C-polysaccharide) detection, Cps detection, and nucleic acid amplification test (24).

\section{IPD}

Meningitis, bacteraemia, parapneumonic pleural effusion, and empyema are types of IPD which present in two conditions. First, the host is colonized by serotype that is never recognized by the immune system before. Second, the host immune system is impaired $(6,25)$.

\section{Pathogenesis}

There are two strategies of pneumococci transmigration through the epithelial and endothelial lining. First, ChoP will bind to the PAF receptor which is located in epithelial and endothelial cells. This binding may lead to pneumococcal transportation to host basal membrane thus causing the invasion of pneumococci. Second, the binding of $\mathrm{Cbp}-\mathrm{A}$ to plgR may initiate the migration of pneumococci between apical to basal membranes. Pneumococci generate hyaluronidase to degrade extracellular matrix in the basal membrane, and its impairment will provoke paracellular invasion (Figure 3) $(19,25)$.

In the bloodstream, bacteria are recognized by innate immune system such as complement system against the antigen through both classic and alternative pathways. Pneumococci enhance their encapsulation that acts to inhibit complement deposition. Pneumococcus is bound to pattern recognition receptor (PRR) including TLR-2, TLR-4, TLR-9, and nucleotide oligomerization domain (NOD)-1 on APCs. It stimulates APCs to release several cytokines such as TNF- $\alpha$, IL-1, and IL-6 which activate the inflammatory process. Bacteremia also induces coagulation cascade, in which in a severe stage, it will be demonstrated as disseminated intravascular coagulation (25).

Meningitis occurs when pneumococcus penetrates into the central nervous system. It translocates into the bloodbrain barrier through either intracellular or intercellular pathway. Pneumococcus attaches to PAF receptor on brain microvascular endothelium and then migrates to the basolateral surface. The alternative routes are Cbp-A that is bound to plgR and laminin receptor, a major component in the basal membrane of brain microvascular. All of those routes are known as an intracellular pathway. The intercellular pathway involves interepithelial tight junction damage that leads pneumococcal translocation into CSF. After crossing the endothelial layer, pneumococcus will disrupt and invade the basal membrane through several methods. In the first method, plasminogen is bound to the bacterial surface. The other methods are the binding of pneumococcus with fibronectin, vitronectin, and collagen (Figure 3) $(19,25)$.

Host immune response will be initiated when pathogenassociated molecular patterns (PAMPs) are recognized by APCs through PRRs. Macrophage in perivascular and meninges, endothelium, astrocyte, and microglial cells will produce pro-inflammatory cytokines including IL-1, TNF- $\alpha$, and IL-6. These cytokines regulate adhesion factors on endothelial cells which mediate leukocyte recruitment into CSF and cause cerebral oedema. Anti-inflammatory cytokines, i.e. IL-10, IL-6, and transforming growth factor (TGF)- $\beta$, also act in the pathogenesis of meningitis. IL-10 will reduce pro-inflammatory cytokines activity and co-stimulatory molecules on macrophage. It also inhibits the ability of neutrophils in phagocytosis.

TGF- $\beta$ plays a role in the differentiation of T-regulator cell and Th-17, inhibits differentiation and maturation of Th-1 and Th- 2 cells, suppresses macrophage activation, and induces microglial cells to produce cytokines. IL-6 will minimize cerebral oedema, impairment of blood-brain barrier, and intracranial pressure. Not only cytokine but also other factors such as chemokines, matrix metalloproteinase, complement system, and coagulation factors are activated in the pathogenesis of pneumococcal meningitis (25).

Parapneumonia pleural effusion or empyema exists when pneumococcus translocates into the mesothelial lining of pleura through the cellular crossing. In animal model, empyema is often caused by either pulmonary infection or direct inoculation. It is rarely led by the invasion of bacteremia. After entering the pleural fluid, pneumococcus activates and releases IL-8, TNF- $\alpha$, vascular endothelial growth factor, and monocyte chemoattractant protein-1. They induce intra-pleural neutrophilia and fibrin formation in pleura (26).

In summary, S. pneumoniae is a coccus bacterium which causes pneumococcal disease. Cps is the major virulence factor, and pneumococci are divided into 97 serotypes based on their Cps type. Aspiration or inhalation of bacteria may lead to interaction between pathogen and host immune system which initiates pneumonia. If the pneumococci penetrate into a sterile body fluid, it is defined as IPD. Diagnostic procedures for pneumococcal detection are still a challenge since positive results may impact the treatment option and prognosis.

\section{Ethics approval and consent to participate}

Not applicable.

\section{Competing interests}

The authors declare that they have no competing interests. 


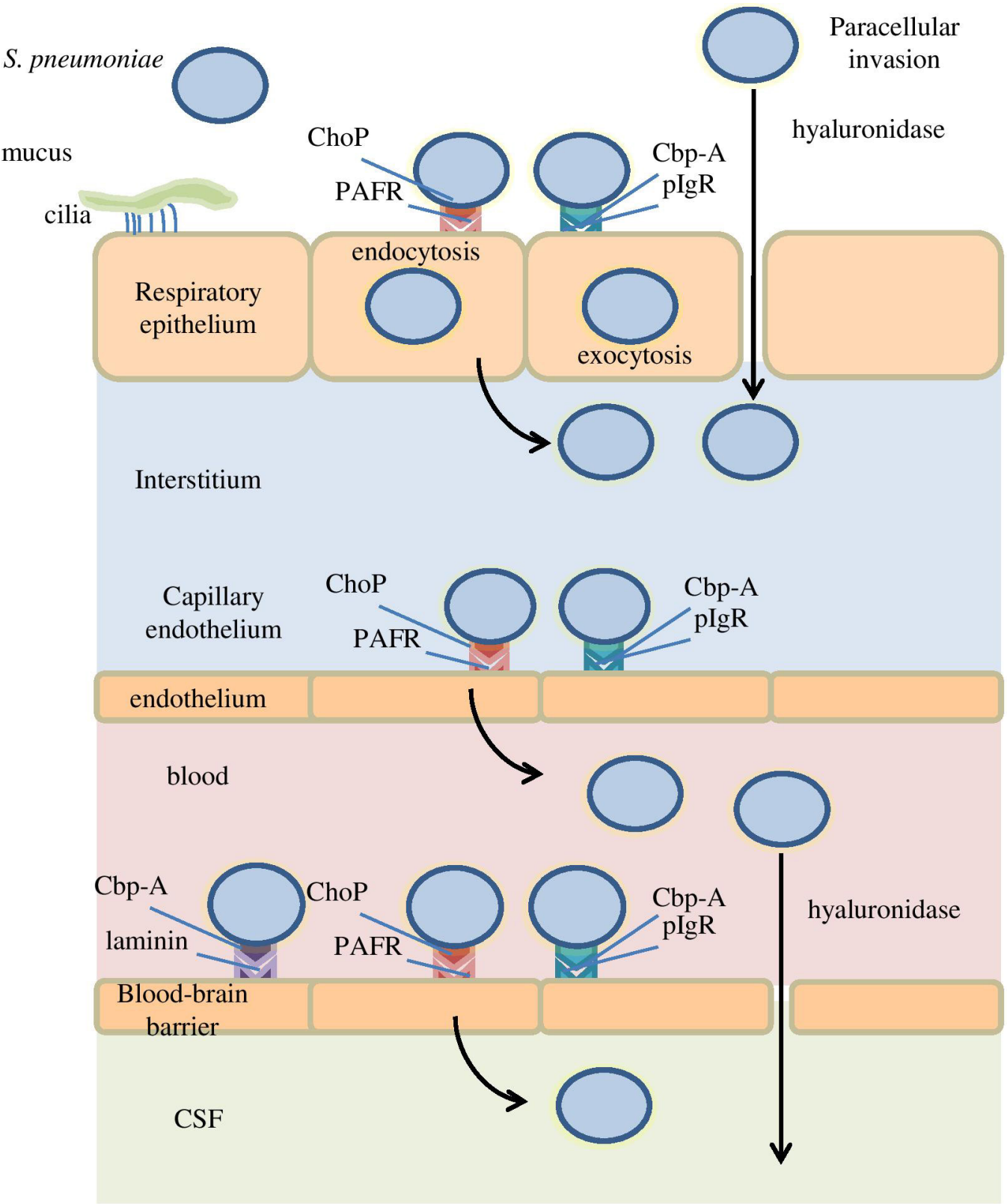

Figure 3. Mechanism of pneumococcal invasion from the respiratory tract to the bloodstream and CSF. The figure is adapted with modification from Wyllie AL, Rümke LW, Arp K, Bosch AA, Bruin JP, Rots NY, et al. Molecular surveillance on Streptococcus pneumoniae carriage in non-elderly adults; little evidence for pneumococcal circulation independent from the reservoir in children. Sci Rep 2016;6:34888. CSF, cerebrospinal fluid.

\section{References}

1. Centers for Disease Control and Prevention. Pneumococcal disease. In: Hamborsky J, Kroger A, Wolfe S. (eds). Epidemiology and Prevention of Vaccine-Preventable Diseases. 13th ed. Washington, DC: Public Health Foundation; 2015; 279-295.
2. Hung IF, Tantawichien T, Tsai YH, Patil S, Zotomayor R. Regional epidemiology of invasive pneumococcal disease in Asian adults: epidemiology, disease burden, serotype distribution, and antimicrobial resistance patterns and prevention. International Journal of Infectious Diseases. 2013;17(6): e364-e373. 
3. Bansal S, Kashyap S, Pal LS, Goel A. Clinical and bacteriological profile of community-acquired pneumonia in Shimla, Himachal Pradesh. The Indian Journal of Chest Diseases \& Allied Sciences. 2004;46(1):17-22.

4. Shah BA, Singh G, Naik MA, Dhobi GN. Bacteriological and clinical profile of community-acquired pneumonia in hospitalized patients. Lung India. 2010;27(2):54-57.

5. Piralam B, Tomczyk SM, Rhodes JC, et al. Incidence of pneumococcal pneumonia among adults in rural Thailand, 20062011: implications for pneumococcal vaccine considerations. The American Journal of Tropical Medicine and Hygiene. 2015;93(6):1140-1147.

6. Dockrell DH, Whyte MK, Mitchell TJ. Pneumococcal pneumonia: mechanisms of infection and resolution. Chest 2012;142(2):482491.

7. Feldman C, Anderson R. Review: current and new generation pneumococcal vaccines. Journal of Infection. 2014;69(4):309-325.

8. Keller LE, Robinson DA, McDaniel LS. Nonencapsulated Streptococcus pneumoniae: emergence and pathogenesis. MBio 2016;7(2):e01792.

9. Todar K. Todar's Online Textbook of Bacteriology. Madison, WI: University of Wisconsin-Madison; 2006. Available from: http:// www.textookofbacteriology.net/.

10. Chewapreecha K. Evolution of Streptococcus pneumoniae during carriage (Dissertation). Cambridge: Cambridge University; 2014.

11. Geno KA, Gilbert GL, Song JY, Skovsted IC, Klugman KP, Jones C, et al. Pneumococcal capsules and their types: past, present, and future. Clinical Microbiology Reviews. 2015;28(3):871-899.

12. Hammerschmidt $S$, Wolff $S$, Hocke A, Rosseau $S$, Müller $E$, Rohde M. Illustration of pneumococcal polysaccharide capsule during adherence and invasion of epithelial cells. Infection and Immunity. 2005;73(8):4653-4667.

13. Steel HC, Cockeran R, Anderson R, Feldman C. Overview of community-acquired pneumonia and the role of inflammatory mechanisms in the immunopathogenesis of severe pneumococcal disease. Mediators of Inflammation. 2013;2013:490346.

14. Simell B, Auranen K, Kayhty H, Goldblatt D, Dagan R, O'Brien $\mathrm{KL}$. The fundamental link between pneumococcal carriage and disease. Expert Review of Vaccines. 2012;11(7):841-855.

15. Van der Poll T, Opal SM. Pathogenesis, treatment, and prevention of pneumococcal pneumonia. Lancet 2009;374(9700):1543-1556.

16. Imohl M, Reinert RR, van der Linden M. Adult invasive pneumococcal disease between 2003 and 2006 in North-Rhine Westphalia, Germany: serotype distribution before recommendation for general pneumococcal conjugate vaccination for children <2 years of age. Clinical Microbiology and Infection. 2009;15(11):1008-1012.

17. Mosser JF, Grant LR, Millar EV, Weatherholtz RC, Jackson DM, Beall $B$, et al. Nasopharyngeal carriage and transmission of Streptococcus pneumoniae in American Indian households after a decade of pneumococcal conjugate vaccine use. PLoS One 2014;9(1):e79578.
18. Wyllie AL, Rümke LW, Arp K, Bosch AA, Bruin JP, Rots NY, et al. Molecular surveillance on Streptococcus pneumoniae carriage in non-elderly adults; little evidence for pneumococcal circulation independent from the reservoir in children. Scientific Reports. 2016;6:34888

19. Weiser JN, Ferreira DM, Paton JC. Streptococcus pneumoniae: transmission, colonization, and invasion. Nature Reviews Microbiology. 2018;16(6):355-367.

20. Syrjanen R. Relationship between nasopharyngeal carriage and acute otitis media due to Streptococcus pneumoniae among Finnish children aged less than two years (Dissertation). Tampere: University of Tampere; 2015

21. Jambo KC, Sepako E, Heyderman RS, Gordon SB. Potential role for mucosally active vaccines against pneumococcal pneumonia. Trends in Microbiology. 2010;18(2):81-89.

22. Ortqvist A, Hedlund J, Kalin M. Streptococcus pneumoniae: epidemiology, risk factors, and clinical features. Seminars in Respiratory and Critical Care Medicine. 2005;26(6):563-574.

23. Madhi SA, Klugman KP. World Health Organisation definition of "radiologically-confirmed pneumonia" may underestimate the true public health value of conjugate pneumococcal vaccines. Vaccine. 2007;25(13):2413-2419.

24. Song JY, Eun BW, Nahm MH. Diagnosis of pneumococcal pneumonia: current pitfalls and the way forward. Infection \& Chemotherapy. 2013;45(4):351-366.

25. Mook-Kanamori BB, Geldhoff M, van der Poll T, van de Beek D. Pathogenesis and pathophysiology of pneumococcal meningitis. Clinical Microbiology Reviews. 2011;24(3):557-591.

26. Wilkosz S, Edwards LA, Bielsa S, Hyams C, Taylor A, Davies RJ, et al. Characterization of a new mouse model of empyema and the mechanisms of pleural invasion by Streptococcus pneumoniae. American Journal of Respiratory Cell and Molecular Biology. 2012;46(2):180-187.

\section{Abbreviation}

APCs, antigen-presenting cells; AM, alveolar macrophage; CAP, community-acquired pneumonia; $\mathrm{Cbp}$, choline-binding protein; ChoP, phosphorylcholine; Cps, polysaccharide capsule; CSF, cerebrospinal fluid; DNA, deoxyribonucleic acid; Ig, immunoglobulin; IL, interleukin; IPD, invasive pneumococcal disease; MARCO, macrophage receptor with collagenous structure; PAMPs, pathogen-associated molecularpatterns; plgR, polymericimmunoglobulin receptor; PRR, pattern recognition receptor; Psp, pneumococcal surface protein; NOD, nucleotide oligomerization domain; NP, nasopharyngeal; PAF, platelet-activating factor; PMN, polymorphonuclear; TGF, transforming growth factor; Th, T helper; TLR, toll-like receptor; TNF, tumour necrosis factor. 